\title{
Potrzeba budowy teorii dydaktycznych jako wymóg rozwoju dydaktyki ogólnej
}

\section{KEYWORDS}

theory, subject of research, goals of cognition, researcher's awareness, model, axiological dilemmas

\begin{abstract}
Piotrowski Eugeniusz, Potrzeba budowy teorii dydaktycznych jako wymóg rozwoju dydaktyki ogólnej [The construction of didactic theories as a requirement for the development of general didactics]. Kultura - Społeczeństwo - Edukacja nr 2(14) 2018, Poznań 2018, pp. 7-23, Adam Mickiewicz University Press. ISSN 2300-0422. DOI 10.14746/kse.2018.14.1.
\end{abstract}

This paper's concern is the need to construct didactic theories in the aspect of the development of general didactics. The author performs an analysis of the various ways the term 'theory' is understood in the many field of scientific inquiry. What follows is a discussion of the problems of scientific cognition, researcher's methodological awareness, as well as the models of pedagogy: the scientist, hermeneutic and praxeological models. Finally, the author draws attention to the sources of researcher's expectations, axiological dilemmas in pedagogical research and potential conflicts of values.

\section{Wstęp}

Człowiek jest istotą społeczną. Jego cechą charakterystyczną jest życie psychiczne, tworzenie kultury, w której żyje i którą przekazuje następnym pokoleniom, zatem może i powinien być obiektem badań, w których wiedzę o nim i o jego rozwoju, pod wpływem oddziaływań dydaktyczno-wychowawczych, buduje się na podstawie obserwacji i doświadczenia, możliwych do poddania wnioskowaniu indukcyjnemu. Jeśli tak, to niezbędne staje się uprawianie przez dydaktyków ba- 
dań empirycznych, które korzystają z teorii naukowych i służą ich budowie. Treść opracowania dotyczy kwestii związanej z koniecznością budowy teorii dydaktycznych niezbędnych dla rozwoju dydaktyki ogólnej jako dyscypliny naukowej.

\section{Sposób rozumienia pojęcia teoria w dyscyplinach naukowych}

Pod pojęciem teoria rozumie się najczęściej uporządkowany i usystematyzowany zbiór twierdzeń odnoszący się do określonej dziedziny rzeczywistości, którego celem jest opisywanie, systematyzowanie i wyjaśnianie faktów oraz przewidywanie przyszłych zdarzeń. W naukach empirycznych przez teorię rozumie się ogół twierdzeń opisujących i określających określone stany rzeczy, zjawiska i procesy w sposób niesprzeczny i dający się zweryfikować. W literaturze metodologicznej spotyka się także określanie tym terminem pewnego systemu ogólnych twierdzeń wyjaśniających daną dziedzinę rzeczywistości, uporządkowanych w taki sposób, iż te o niższym szczeblu ogólności wyprowadzone są z twierdzeń o wyższym szczeblu ogólności (Malewski, 1963: 63). Tak rozumiana teoria, sprowadzona do funkcji eksplikacyjnej, nie może znaleźć zastosowania w pedagogice, a tym samym również w dydaktyce, gdyż wyjaśnianie zjawisk dotyczących określonej rzeczywistości nie stanowi wystarczającej podstawy teoretycznej do ich przekształcania. Jak zatem może być rozumiana teoria pedagogiczna? Jako zbiór twierdzeń odnoszących się do danego wycinka rzeczywistości, które charakteryzują się pewnym stopniem ogólności, to znaczy wyrażają sądy za pomocą terminów o ściśle wyznaczonych zakresach dotyczących całych klas rzeczy i zjawisk, dzięki czemu umożliwiają wysuwanie uzasadnionych oczekiwań oraz przewidywań, a także odznaczają się określonym poziomem logicznej spójności, co zabezpiecza przed wzajemnym wykluczaniem się (Muszyński, 1970: 56). W pedagogice wyróżnia się:

- teorię nauczania i uczenia się; jej przedmiot zainteresowań stanowią cele, treści, prawidłowości procesu nauczania i uczenia się, zasady nauczania, metody nauczania, formy organizacyjne i środki dydaktyczne;

- teorię wychowania, której przedmiotem zainteresowań są cele, treści, metody, formy organizacyjne, środki wychowania społeczno-moralnego, estetycznego, fizycznego oraz ich uwarunkowania i skutki.

Dydaktyka jako jeden z czterech filarów pedagogiki znajduje się od dość dawna w stadium dezintegracji. Świadczy o tym brak spójności jej twierdzeń, nierzadko ich sprzeczność. Naturalną tendencją każdej dyscypliny naukowej jest dążenie do integracji. Idealną sytuacją, nieosiągalną w dydaktyce ogólnej, byłaby taka, gdzie 
jedna teoria wyjaśniałaby relacje, jakie zachodzą między wszystkimi elementami jej pola badawczego. Ze zrozumiałych względów, o czym już wspomniałem wcześniej, jest to niemożliwe.

Dążąc do przezwyciężania dezintegracji, dydaktyka ogólna może kroczyć dwoma drogami:

1) budowania tak zwanych teorii cząstkowych (niższego rzędu), czego przykład stanowią teorie: nauczania zespołowego, nauczania problemowego, nauczania programowanego, nauczania wychowującego. Pojawiają się tu szczególne utrudnienia w postaci wielości teorii cząstkowych odnoszących się do tego samego pola badawczego, jak również przy wykorzystywaniu psychologicznych teorii uczenia się w praktycznych przypisach postępowania dydaktycznego, przy rezygnacji z tworzenia własnych teorii. Jest oczywiste, że teorie tworzone przez inne dyscypliny i odnoszone do procesu dydaktycznego upraszczają w znaczący sposób rzeczywistość dydaktyczną.

Każda teoria spełniać powinna kilka warunków:

- dokładnie wyznaczyć przedmiot badań: zawierać dokładnie określoną zhierarchizowaną i niesprzeczną sieć pojęciową, a także zbiór uporządkowanych twierdzeń i hipotez oraz metod ich uzasadniania;

- umożliwiać wyjaśnianie zjawisk i prawidłowości związanych z przedmiotem badań oraz przewidywanie stanów rzeczy w przyszłości i stanowić podstawę do działalności praktycznej;

- określać swój stosunek do teorii nadrzędnych (wyższego szczebla).

Czy zatem dysponujemy w pedagogice, a w szczególności w dydaktyce, teoriami, które spełniałyby wyżej wymienione warunki? Wydaje się, że nie w pełni. Mamy tu raczej do czynienia z mniej lub bardziej rozbudowanymi koncepcjami o charakterze przedteoryjnym.

Tak więc trzeba postawić pytanie: czy należy rezygnować z prób budowy teorii dydaktycznych? Wydaje się, że nie, gdyż nie można tracić szansy na ich doskonalenie. Ponadto warto zwrócić uwagę na to, że każda z teorii cząstkowych wnosiła nowe elementy do praktyki dydaktycznej. Na przykład teorie doboru treści kształcenia ukazały ich ewolucję, a ponadto umożliwiły ich doskonalenie i coraz lepsze dostosowanie do wymagań czasów współczesnych. Teoria nauczania zespołowego ukazała rolę procesów osobotwórczych funkcjonujących w grupie społecznej. Teoria nauczania problemowego przyczyniła się do rozwoju samodzielności poznawczej uczniów. Teoria nauczania programowanego przybliżyła wiedzę o psychologicznych mechanizmach uczenia się, a także zwróciła uwagę na konieczność dbałości o logi- 
kę treści kształcenia. Teoria wielostronnego kształcenia ukazała możliwość stosowania różnych dróg uczenia się w zależności od realizowanych celów. Teoria nauczania wychowującego ukazała możliwość jednoczesnej realizacji celów nauczania i wychowania w procesie kształcenia;

2) dążąc do przezwyciężania dezintegracji, dydaktyka dokonuje syntezy dotychczasowego dorobku. Warto podkreślić, że w swym rozwoju przechodzi ona przez fazy rozgałęzienia i syntezy. W każdym kolejnym cyklu rozgałęzienia są coraz liczniejsze, a tym samym syntezy stają się coraz trudniejsze (Kruszewski, 1987: 9). Każda synteza prowadzi do inspiracji twórczej zarówno teoretyków doskonalących jej istotę, jak i praktyków, którzy starają się jej idee wprowadzić w życie. Taką syntezę dydaktyki okresu dwudziestolecia międzywojennego zawarł Bogdan Nawroczyński w bardzo wartościowej pracy Zasady nauczania. Syntezę dydaktyki po II wojnie światowej znajdujemy w pracach Wincentego Okonia, zwłaszcza w kolejnych wydaniach Zarysu dydaktyki ogólnej, gdzie wyraźnie widać wpływ ideologii socjalistycznej na dydaktykę. Wincenty Okoń podjął także próbę dokonania syntezy dydaktyki lat sześćdziesiątych w pracy Podstawy wykształcenia ogólnego.

Niewątpliwą zaletę takich opracowań stanowi to, że umożliwiają one asymilację wyników badań pochodzących z innych dyscyplin, nie zawsze zgodnych z podstawami syntezy. Kolejne syntezy przyczyniły się do tego, że polscy nauczyciele, mimo w przeszłości niesprzyjających sytuacji, potrafią się porozumiewać za pomocą języka dydaktyki z obszarami badawczymi, jak również obszarami dotyczącymi procesu lekcyjnego.

Znamienną cechą praktyki badawczej w pedagogice, jak również $\mathrm{w}$ dyscyplinach pokrewnych, psychologii i socjologii, staje się zacieranie różnic między sposobami dochodzenia przez badaczy do rezultatów badań a sposobami ich empirycznego uzasadniania. Coraz częściej można zaobserwować zwiększającą się przydatność naukowej wiedzy pedagogicznej dla praktyki edukacyjnej, co powoduje wzrost oczekiwań pod adresem pedagogiki. Efekty jej badań stają się niezbędne dla doskonalenia praktyki edukacyjnej. Badania pedagogiczne można charakteryzować według różnych kryteriów. Jeśli weźmiemy pod uwagę kryterium celów, to wyodrębnia się: badania opisowe, diagnostyczne, eksperymentalne i wyjaśniające (eksplikacyjne i weryfikacyjne). Jeżeli za punkt wyjścia do kategoryzacji posłużą założenia poznawcze i metodologiczne przyjęte przez badacza, to podzielimy je na badania empiryczne ilościowe i jakościowe (istotnościowe). Biorąc pod uwagę kryterium czasu i przestrzeni, wyodrębnić można badania historyczne i porównawcze. Jeśli jednak przyjmiemy założenie, że pedagogika jest zarazem na- 
uką teoretyczną i praktyczną, to wysoce zasadna wydaje się kategoryzacja badań pedagogicznych dokonana przez Stanisława Palkę, według którego układ problemów badawczych tworzy kontinuum na osi teoretyczność-praktyczność. Idąc tym tokiem myślenia, wyróżnia on badania:

1) metateoretyczne, metametodologiczne

Ten rodzaj badań wiąże się ze statusem pedagogiki jako dyscypliny naukowej, a więc jej terminologią, prawidłowościami, które formułuje, sposobami budowania teoretycznej wiedzy pedagogicznej, metodologią badań empirycznych, ilościowych i jakościowych. Tego typu badania wskazują na świadomość naukową pedagogów i służą diagnozowaniu stanu rozwoju pedagogiki, projektowaniu i prognozowaniu poszukiwań poznawczych;

2) teoretyczne

Dzięki nim możliwe staje się budowanie teoretycznej wiedzy pedagogicznej. Obejmuje ona proces wychowania, kształcenia i samokształcenia jednostki w perspektywie całożyciowej. Jej podstawę stanowią uogólnienia będące efektem empirycznych badań ilościowych i jakościowych. Wyniki tych badań wskazują na stan rozwoju pedagogiki teoretycznej. Ten nurt jest charakterystyczny dla badaczy reprezentujących pedagogikę zorientowaną teoretycznie. Efekty ich prac z powodzeniem mogą być przetwarzane i wykorzystywane dla potrzeb praktyki pedagogicznej;

3) teoretyczno-praktyczne

Wyniki tych badań odgrywają podwójną rolę. Przeprowadzane są one zarówno ze względu na tworzenie systemu teoretycznej wiedzy pedagogicznej, jak i na potrzeby praktyki wychowania, kształcenia oraz samokształcenia jednostki. Ten nurt badań jest podwójnie zapośredniczony w praktyce: - badacze na podstawie doświadczeń zebranych w trakcie obserwacji i analizy praktyki formułują problemy badawcze o znacznym stopniu ogólności. Ich rozwiązania prowadzą do odkrywania i formułowania prawidłowości pedagogicznych,

- badacze dokonują weryfikacji lub falsyfikacji konstruktów teoretycznych, a także hipotez badawczych odnoszących się do konkretnej praktyki wychowawczej i dydaktycznej, wpływając w ten sposób na rozwój teoretycznej wiedzy pedagogicznej, tworząc przyczynki do zmian w zakresie praktyki;

4) ściśle praktyczne

Służą rozwiązywaniu problemów praktycznych i doskonaleniu bieżącej praktyki w zakresie zjawisk pozytywnych i negatywnych zarówno wychowawczych, jak i dydaktycznych. Tego typu badania mają zazwyczaj zasięg 
lokalny. Ich wyniki przyjmują postać raportów i ekspertyz przygotowywanych na zamówienie administracji lokalnej. Nie oznacza to, że nie mogą one służyć do dokonywania analiz teoretycznych (Palka, 2006: 97-109).

\section{Cele poznania naukowego}

Nie każde poznanie można uznać za naukowe. Aby można je było za takie uznać, musi ono urzeczywistniać określone cele zewnętrzne i wewnętrzne. Te pierwsze wynikają z funkcji, jaką pełni nauka w społeczeństwie: realizacji określonych zadań teoretycznych lub praktycznych. Cele wewnętrzne to te, które stawia sobie uczony w swojej pracy badawczej; mają one charakter poznawczy. Rolą badacza jest poznanie prawdy, danie prawdziwego obrazu określonego wycinka rzeczywistości, tej, którą bada. Zatem celem poszukiwań poznawczych badacza jest taka prawda, która go interesuje. Ma ona następujące, ściśle powiązane i wzajemnie się warunkujące cechy: ogólność, ścisłość, wysoki poziom zawartości informatywnej, pewność, prostota. Przy czym trzeba zwrócić uwagę na to, że związki między poszczególnymi cechami mogą mieć charakter pośredni. Wśród pięciu wymienionych cech centralne miejsce zajmuje zawartość informatywna; to właśnie ona warunkuje bezpośrednio stopień sprawdzalności wiedzy. Podkreślenia wymaga fakt, że „im więcej dane twierdzenie (hipoteza badawcza) mówi o rzeczywistości, im bogatsze jest w treść, im wreszcie więcej można z niego wyprowadzić różnorodnych konsekwencji logicznych i doświadczalnych, tym łatwiej i dokładniej można je będzie sprawdzić (liczniejszy i bardziej różnorodny będzie materiał empiryczny, na którym twierdzenie będzie potwierdzone)" (Brzeziński, 2007: 225-226). Informatywna zawartość wiedzy warunkowana jest poziomem jej ogólności, wyrażającej się liczbą wniosków teoretycznych i empirycznych, które na jej gruncie da się wyprowadzić. Tworzenie nauki opiera się na określonej strategii. Badacze często stosują strategię „wyprzedzania rzeczywistości”. Odgrywa ona szczególną rolę w badaniach pedagogicznych, gdyż pedagogika, oprócz wielu innych, spełnia też funkcję prewidystyczną. Jej istota sprowadza się do tego, że analizując aktualne stany rzeczy, stara się określić ich przyszłość. Dlatego badacze w dziedzinie pedagogiki nie mogą koncentrować się wyłącznie na problemach bieżących, lecz formułują problemy o rozszerzonym zakresie pola badawczego, tworząc w ten sposób niejako rodzaj wiedzy „na zapas”. Wskutek tego liczba badanych problemów naukowych znacznie się zwiększa, prowadzi to jednak do uzyskiwania dodatkowych korzyści ze zgromadzonej wiedzy zapasowej. 


\section{Świadomość metodologiczna badacza}

Świadomość metodologiczna pojmowana jest jako jeden z podstawowych regulatorów procesu badania naukowego (Brzeziński, 2007: 48-49). Mianem czynności naukowo-badawczych przyjęło się określać podejmowanie przez badacza lub grupę badaczy (posiadających kwalifikacje metodologiczne) czynności, których bezpośrednim lub pośrednim rezultatem jest urzeczywistnianie celów poznania naukowego. „Świadomość metodologiczną można zatem pojmować jako pewien system przekonań, które da się wyartykułować w postaci odpowiednich zdań normatywnych i deryktywalnych (prewidystycznych)” (Kmita, 1980: 31). „Przekonania konstytuujące świadomość metodologiczną mogą być zatem rozumiane jako istotny składnik paradygmatu teoretyczno-metodologicznego (w rozumieniu np. Kuhna) poznania naukowego w ogóle - bądź wybranej jego dyscypliny lub grupy dyscyplin - wyznaczającego podmiot(y) oraz cel(e) poznania naukowego i dopuszczalne sposoby jego (ich) osiągania" (Pawłowski, 1988: 206). Czym jest zatem świadomość metodologiczna?

Świadomość metodologiczna jest systemem reguł ustalających uznane sposoby uprawiania badań w ramach danej dyscypliny naukowej. Reguły metodologiczne określają, jaki zbiór czynności musi się składać na praktykę naukowo-badawczą oraz w jaki sposób te czynności mają być wykonywane. Kierując się treścią reguł, Zbigniew Spendel proponuje następującą ich klasyfikację:

1) reguły wskazujące cele badawcze (normy metodologiczne):

- wskazujące cele wiodące i ewentualnie pośrednie,

- określające kryteria osiągania celów,

- określające standardową problematykę badawczą,

- określające standardy czynności badawczych;

2) reguły określające sposoby realizacji czynności badawczych (dyrektywy metodologiczne):

- formułowania celów operacyjnych,

- projektowania sposobów osiągania celów operacyjnych:

- wytwarzania wyniku,

- realizowania czynności przygotowawczych i pomocniczych;

- kontroli (i ewentualnie korekty) przebiegu czynności badawczych,

- oceny urzeczywistnienia celów operacyjnych (Spendel, 2005: 27).

Biorąc pod uwagę formalny punkt widzenia, dyrektywom metodologicznym można nadać postać procedur lub heurystyk. Procedury (a czasami algorytmy) szczegółowo określają kolejność wykonywania pewnej skończonej liczby czynności, prowadzących zazwyczaj do urzeczywistnienia celu (np. al- 
gorytmy wnioskowania statystycznego). Przekładają się bezpośrednio na plan działania i mogą być przedstawione w postaci schematów postępowania w określonych sytuacjach. Heurystyki to ogólnie określane ramy (warunki brzegowe) i schematy możliwych do podjęcia działań, które wprawdzie nie zapewniają w niezawodny sposób osiągnięcia celu, jednak ich wykonanie istotnie zwiększa prawdopodobieństwo jego urzeczywistnienia; heurystyki każdorazowo muszą być uszczegółowione, zanim staną się podstawą konkretnego działania (Spendel, 2005: 27).

Trzeba podkreślić, że w badaniu naukowym reguły heurystyczne odgrywają znacznie donioślejszą rolę niż reguły algorytmiczne. Świadomość metodologiczna badacza nie może się sprowadzać do gotowych przepisów, według których prowadzi on badania naukowe. Stanowi ona system narzędzi i środków, za pomocą których badacz będzie w stanie skonstruować spełniającą wymogi norm metodologicznych procedurę badawczą, umożliwiającą mu osiągnięcie założonych celów poznania naukowego (Brzeziński, 1996: 75).

Najczęściej spotykana konceptualizacja świadomości metodologicznej w psychologii oraz w pedagogice obejmuje trojakiego rodzaju twierdzenia:

1) wyrażające podstawowe przekonanie na temat ontycznej struktury rzeczywistości, w uproszczeniu - przedstawiające ostateczne racje pozwalające postawić i zrozumieć pytanie „co jest przedmiotem poznania naukowego?”. Obejmują też niektóre przesłanki do udzielenia na nie odpowiedzi. Jest to tak zwana perspektywa ontologiczna;

2) wyrażające podstawowe przekonania na temat poznawania świata, a także przesłanki do wyboru najodpowiedniejszego języka do jego opisu, w uproszczeniu - takie twierdzenia, które przedstawiają podstawowe narzędzia epistemologiczne umożliwiające sformułowanie kryteriów oceny formalnej poprawności odpowiedzi udzielanej na postawione pytania. Jest to tak zwana perspektywa epistemologiczna. Zalicza się tu również zasady regulujące przebieg praktyki naukowo-badawczej, które są opisywane przez filozofię nauki w postaci teorii rozwoju poznania naukowego;

3) opisujące zasady posługiwania się rozmaitymi technikami badawczymi i metodami analizy uzyskanych danych, w uproszczeniu - twierdzenia, które werbalizują przepisy na uzyskanie w badaniu uzasadnienia dla odpowiedzi udzielonej na pytanie badawcze. Stanowi je tak zwana wiedza o modelach badań.

Charakteryzując społeczną świadomość metodologiczną badacza, nie można pominąć perspektywy aksjologicznej uprawiania nauki. Mieści się ona w obrębie zbioru wartości, których realizacja wyznacza kierunki i metody badań. Tak więc 
społeczna świadomość metodologiczna w rozumieniu Jerzego Brzezińskiego odznacza się hierarchiczną strukturą i obejmuje trzy poziomy: ontologiczny, epistemologiczny i metodologiczny.

Indywidualna świadomość metodologiczna $\mathrm{w}$ rozumieniu Brzezińskiego to pewna liczba akceptowanych przez danego badacza teorii metodologicznych, a mianowicie teorii:

- badanego obiektu;

- badania empirycznego;

- statystyki;

- interpretacji rezultatu badawczego.

Treści składające się na wyszczególnione wyżej poziomy 1 i 2 świadomości metodologicznej, rekonstruowane oraz werbalizowane na gruncie określonej koncepcji filozoficznej i oparte na odpowiednich przekonaniach ontologicznych i epistemologicznych, waloryzują konkretne cele poszczególnych czynności wykonywanych przez badaczy, wiążąc wartości (uchwytne praktycznie) z wartościami światopoglądowymi, czyli nieinstrumentalnymi wartościami nadrzędnymi (Kmita, 1982: 176).

Pogląd ten odnosi się do nauk o charakterze monoparadygmatycznym. U podstaw społecznej świadomości metodologicznej, rozumianej jako regulator działalności naukowo-badawczej, tkwi założenie, że istnieje jedyne optymalne czy poprawne rozwiązanie jakiegoś badanego problemu, który polega na podjęciu zbioru określonych decyzji metodologicznych stanowiących najwłaściwszą strategię działań umożliwiających jego rozwiązanie. Przy czym badacz może nie dostrzegać tej strategii w sytuacji, kiedy jego indywidualna świadomość metodologiczna znacznie odbiega od treści społecznej świadomości metodologicznej, bądź też wtedy, kiedy zadziałały pozametodologiczne determinanty przebiegu poznania naukowego. Nie oznacza to jednak, że w subiektywnej indywidualno-przeżyciowej (psychologicznej) perspektywie konkretnego badacza jakikolwiek problem mógłby mu się jawić jako taki, który ma tylko jedno rozwiązanie.

Pedagogika jest dyscypliną wieloparadygmatyczną, zatem w grę muszą tu wchodzić alternatywne świadomości metodologiczne. W metodologicznej literaturze pedagogicznej spotykamy trzy modele jej uprawiania, a mianowicie: scjentystyczny, hermeneutyczny i prakseologiczny.

Model scjentystyczny pedagogiki zwraca uwagę na ścisłość pojęć pedagogicznych. Jego zwolennicy zmierzają do nadania pojęciom pedagogicznym wyraźnych empirycznych kryteriów stosowalności. Starają się, by pojęcia operacyjne czy behawioralne mogły być poddane obserwacji i pomiarowi. W tej perspektywie metodologicznej zwraca się uwagę na badanie zachowań jednostek i grup spo- 
łecznych zarówno w naturalnych, jak i specjalnie organizowanych sytuacjach edukacyjnych. Badane zjawiska pedagogiczne są tu sprowadzane do obserwowanych faktów naukowych. Scjentystyczny punkt widzenia postuluje usunięcie z języka pedagogiki zdań oceniających. „Obecność ocen może utrudniać zajęcie wobec badanych zjawisk obiektywnej, bezstronnej postawy”, a także - na skutek skażenia subiektywną domieszką - uniemożliwić „precyzyjny opis uzyskanych wyników badań" (Pawłowski, 1988: 206).

Dzięki pomiarowi możliwe staje się badanie siły wzajemnego oddziaływania zjawisk pedagogicznych. Scjentyzm, jak twierdzi Jerzy Kmita, opiera się na trzech następujących założeniach:

1) między sądem dotyczącym danego stanu rzeczy a tymże stanem rzeczy może zachodzić dwojaki stosunek: albo sąd jest zgodny z owym stanem rzeczy (jest prawdziwy), albo jest z nim niezgodny (jest fałszywy);

2) uzyskanie sądów prawdziwych jest jedyną możliwą formą poznania;

3) poznanie pojęciowe jest wartością podstawową (Kmita, 1982: 141).

W ścisłym związku ze scjentystycznym modelem pedagogiki pozostaje behawioryzm. Ujmuje on człowieka jako jednostkę zdeterminowaną przez środowisko zewnętrzne i traktuje go w sposób zewnątrzsterowny i nieautonomiczny.

Model hermeneutyczny pedagogiki za punkt wyjścia przyjmuje doświadczenie wewnętrzne jednostki, a więc jej motywy, postawy, przekonania, cele, wartości i możliwości, które kierują jej zachowaniem w różnych sytuacjach edukacyjnych. Metodologiczną konsekwencją tak rozumianej pedagogiki jest próba badania przejawów doświadczenia wewnętrznego za pomocą takich metod jak: introspekcja, autobiografia, interpretacja humanistyczna. Zjawiska pedagogiczne zostają tu sprowadzone do doświadczenia wewnętrznego jednostki. Istota badania sprowadza się do zrozumienia czyichś intencji, celów i dążeń. Temu modelowi obca jest matematyzacja, gdyż, jak twierdzi Janusz Gnitecki, prowadzi ona do utraty wartościowej wiedzy o jednostce i grupie społecznej, zwłaszcza tej, która nie da się ująć w prawa ilościowe (Gnitecki, 2006: 71). Rozumienie rzeczywistości wychowawczej przebiega na płaszczyźnie kilku perspektyw:

1) rozumienia wychowanka przez wychowawcę;

2) rozumienia przez pedagoga procesu uczenia się dziecka i jego rozwoju osobowego;

3) rozumienia postawy wychowawcy z perspektywy wychowanka, samego wychowawcy i perspektywy obiektywno-idealnej;

4) rozumienia szerokiego spektrum instytucji kształcąco-wychowujących jako części rzeczywistości wychowawczej; 
5) rozumienia pozytywnych i negatywnych zjawisk pedagogicznych z punktu widzenia środowisk pozawychowawczych i ich interesów: społecznych, ekonomicznych i kulturowych;

6) hermeneutycznej interpretacji wzajemności praktyki i teorii, jako związku o charakterze kołowym, a nie sprzężenia zwrotnego (Ablewicz, 1998: 34-35).

Model prakseologiczny pedagogiki bierze pod uwagę dążenie do podkreślenia skuteczności działań pedagogicznych. Staje się to możliwe, jak twierdzi Janusz Gnitecki, w warunkach zwiększenia stopnia określoności trzech podstawowych kategorii pedagogiki praktycznie zorientowanej, a mianowicie celów, działań i warunków. Pedagogika praktyczna obejmuje trzy rodzaje refleksji: nad teleologią edukacyjną, nad działalnością edukacyjną, nad warunkami skuteczności działań pedagogicznych (Gnitecki, 2006: 72). Pedagogika praktyczna zmierza w kierunku opracowania dyrektyw, wskazówek dla praktyki edukacyjnej. Wymienione trzy modele rozumienia pedagogiki są bardzo często sobie przeciwstawiane, co prowadzi do ujawniania się kontrastów w ujmowaniu istoty nauk pedagogicznych, a także do zróżnicowanego ujmowania zmiany jako kategorii badawczej w pedagogice. Celem pedagogiki empirycznej jest wyjaśnienie zmiany w jednostce, celem pedagogiki hermeneutycznej - interpretowanie zmiany z punktu widzenia wartości nadających sens ludzkiemu życiu, a pedagogiki prakseologicznej - poszukiwanie sposobów dokonywania zmiany w jednostce.

Opowiedzenie się badacza za określonym sposobem rozumienia pedagogiki jako nauki wiąże się z przyjęciem odmiennego nastawienia percepcyjnego, czyli wstępnego przygotowania umysłu badacza do odbioru określonej informacji. Warto podkreślić, że siła nastawienia może być tak duża, iż spostrzeżenie będzie nieadekwatne do rzeczywistości (Nęcka, Orzechowski, Szymura, 2006: 296-297), ponieważ utrudnia kategoryzację badanych obiektów i przyczynia się do popełniania błędów. Nastawienie wynikające z głęboko utrwalonych struktur wiedzy, stereotypów i uprzedzeń może w znacznym stopniu zakłócać proces badawczy i prowadzić do zbyt subiektywnego spojrzenia na badane zjawisko.

Ważnym czynnikiem w badaniach pedagogicznych są oczekiwania badacza. Czynnik ten jest źródłem samospełniającego się proroctwa, efektu pozytywnych oczekiwań bądź stronniczości eksperymentu.

\section{Źródła oczekiwań badacza}

W literaturze przedmiotu wymienia się najczęściej trzy rodzaje źródeł: źródło osobowościowe, wiedzę badacza oraz dane o osobach badanych uzyskane przed rozpoczęciem badań. 
Do źródeł osobowościowych należy zaliczyć postawy badacza, jego przekonania, uznawane przez niego wartości. Badania porównawcze przeprowadzone wśród badaczy o wysokim i niskim poziomie oczekiwań badawczych pozwoliły, jak twierdzi Brzeziński, na stworzenie ich sylwetek psychologicznych. Główną cechą sylwetki badacza o wysokim poziomie oczekiwań jest autorytaryzm i duża doza dogmatyzmu w stylu myślenia, brak tolerancji na odmienność poglądów, sztywność myślenia, poszukiwanie aprobaty społecznej, duży opór w przyjmowaniu informacji niepotwierdzających oczekiwań badacza (Brzeziński, 1996: 90).

Drugim źródłem jest, jak wspomniano, wiedza badacza (znajomość aktualnych teorii pedagogicznych, aktualnych wyników badań, metodologii pedagogiki, a także jego kompetencje jako badacza).

Trzecie źródło tkwi poza badaczem. Stanowią je dane o badanych osobach i innych obiektach uzyskane przed rozpoczęciem badania. Te dane mają dwojaki charakter: obiektywny i subiektywny. Danymi obiektywnymi są na przykład: stan zdrowia badanych uczniów, ich pochodzenie społeczne i dotychczasowe wyniki nauczania; danymi subiektywnymi - charakterystyki badanych wynikające z ich przynależności do określonych organizacji, grup społecznych, mniejszości narodowych, wspólnot wyznaniowych itd.

Warto podkreślić, że te same wyniki badań będą inaczej interpretowane w zależności od tego, jakie miejsce na skali autorytaryzmu i dogmatyzmu zajmuje badacz. „Będzie on osoby badane, z grupy spodziewanych zachowań potwierdzających hipotezę badawczą, traktował odmiennie od osób badanych z grupy spodziewanych zachowań hipotezy badawczej niepotwierdzających" (Brzeziński, 1996: 90). Dość częstym zjawiskiem występującym u badaczy jest ich nastawienie na potwierdzanie hipotez roboczych za wszelką cenę.

W refleksji nad uprawianiem pedagogiki ważna jest świadomość etyczna badacza. Składają się na nią przekonania odnoszące się do podejmowanych przez niego czynności, które podlegają kwalifikacji moralnej. Na strukturę treściową świadomości etycznej składają się trzy rodzaje przekonań:

1) przekonania odnoszące się do tego, co stanowi wartość moralną. Jakie stany rzeczy i według jakich zasad będą kwalifikowane jako moralnie dobre, a jakie jako moralnie złe. Tego typu przekonania decydują o katalogu wartości moralnych stanowiących powinność badacza i realizowanych przez niego;

2) przekonania odnoszące się do sposobów realizacji obowiązku moralnego, jaki wynika $\mathrm{z}$ akceptacji pewnych przekonań ewaluatywnych. Mają one charakter regulatywny i decydują o warunkach i sposobie podejmowania czynności będących wyrazem aprobaty danych wartości moralnych. Wskazują one również na to, jakie czynności są niedozwolone; 
3) metaprzekonania - odpowiadają za ustalenie hierarchii wartości moralnych oraz ich stosunek do wartości poznawczych (Spendel, 2005: 51).

Wróćmy zatem do problemu świadomości metodologicznej badacza w procesie badawczym. Podkreślić trzeba, że badacz dość często staje przed wyborem orientacji metodologicznej, dokonuje wyboru pewnego modelu świata, na przykład determinizmu versus indeterminizmu. Decydując się na określoną teorię badanego obiektu, przesądza, jaka będzie treść formułowanych pytań badawczych. Zmuszony jest dokonać wyboru między konkurencyjnymi i uzupełniającymi się modelami badań. Podjęte przez badacza decyzje mogą się stać przedmiotem oceny bądź samooceny, a zatem mamy tu do czynienia z wyborem pomiędzy akceptacją a odrzuceniem lub pomiędzy różnymi stopniami akceptacji. Zarówno dokonywanie wyborów, jak i wydawanie określonych ocen z punktu widzenia determinant je powodujących, na gruncie posiadanej wiedzy, trudne są do określenia.

„Kryteria słuszności decyzji i ocen, poza wymogiem wewnętrznej spójności, konsekwencji w ich podejmowaniu i wydawaniu, nie są do końca jasne" (Brzeziński, 1996: 74-79). Brzeziński twierdzi, że to właśnie akceptowane przez badacza teorie metodologiczne wyznaczają owe decyzje metodologiczne (Brzeziński, 1996: 79). Stanowisko to podaje w wątpliwość Zbigniew Spendel. Twierdzi on mianowicie, że:

1) nie jest tak, że badacz dysponuje (w sensie znajomości stosowanych twierdzeń) zawsze tylko jedną teorią metodologiczną;

2) przedkładanie danej teorii metodologicznej nad teorię do niej alternatywną nie daje się sprowadzić do „otrzymania w spadku” tych poglądów po swoich mistrzach, zwłaszcza w świecie globalnego przepływu informacji;

3) teorie metodologiczne nie są jakoś dane, przedstawione (wykluczałoby to wszelki rozwój warsztatu naukowo-badawczego), przeciwnie, ktoś musi je formułować (jako jedną z wielu możliwości) (Spendel, 2005: 39).

Wątpliwości te odnieść trzeba przede wszystkim do dyscyplin wieloparadygmatycznych.

We wszelkich badaniach naukowych, w tym także pedagogicznych, ważną rolę odgrywa intuicja badacza. Sam termin „poznanie intuicyjne” odnosi się do szerokiej kategorii zjawisk dotyczących nabywania wiedzy, uczenia się, pamięci, a także rozwiązywania problemów. Istota poznania intuicyjnego sprowadza się do tego, że badacz wykonuje złożone czynności poznawcze w trakcie rozwiązywania problemów, zupełnie nie uświadamiając sobie istotnych elementów tego procesu, nierzadko mając w swoim repertuarze określone sprawności poznawcze lub wiedzę niezbędną do rozwiązywania tych problemów. Cechą charakterystyczną intuicji jest zdolność umysłu badacza do działania w warunkach braku pełnego 
uświadomienia przyczyn bądź mechanizmów tego działania. Intuicyjny charakter mają niektóre z wydawanych sądów. Badacz jest wtedy przekonany, że coś wie, lecz nie wie, skąd wie.

Ma zatem subiektywne poczucie nagłości, oczywistości i aprioryczności swojego sądu. Sąd intuicyjny jest nagły, bo w doświadczeniu wewnętrznym nie stanowi końcowego ogniwa dłuższego ciągu rozumowania. Jest oczywisty, gdyż nie wymaga uzasadnień, jego prawdziwość nie budzi wątpliwości. Jest aprioryczny, bo nie wydaje się badaczowi, że powstał na podstawie doświadczenia i wiedzy, lecz w wyniku tajemniczego olśnienia. (Nęcka, Orzechowski, Szymura, 2006: 564)

Można więc powiedzieć, że intuicja to umiejętność dostrzegania sensu, którego nie da się wyrazić w sposób werbalny. Psychologowie o orientacji kognitywnej starają się określić mechanizm powstawania sądu intuicyjnego, a także nieuświadomione przesłanki, na podstawie których powstaje. Samo pojęcie sądu intuicyjnego, jak twierdzą Edward Nęcka, Jarosław Orzechowski i Błażej Szymura, odnosi się do trzech kategorii zjawisk. Są to, po pierwsze, sądy, których badacz nie potrafi uzasadnić. Opierają się one na przeczuciach i są przeciwieństwem sądów o charakterze racjonalnym. W drugim znaczeniu sąd intuicyjny traktowany jest jako naiwny, wynikający z doświadczenia potocznego, a nie ze zweryfikowanych empirycznie procedur. Poznanie takie może wynikać z niedokładnych i jednostkowych obserwacji, a także ze skłonności do pochopnego uogólniania. „Nauka też nie ma monopolu na prawdę - można zaryzykować twierdzenie, że jej rozwój polega na nieustannym zastępowaniu naiwnych, niesprawdzonych i błędnych teorii modelami lepiej dopasowanymi do wyników badań" (Nęcka, Orzechowski, Szymura, 2006: 569). Z całą odpowiedzialnością można powiedzieć, że wiele twierdzeń naukowych opiera się na przesądach, bezkrytycznie przyjmowanych i powtarzanych przez pokolenia uczonych. Wiedza prawdziwie naukowa, czyli sprawdzona, cechuje się tym, że nader często godzi w powszechnie przyjęte przekonania i naturalne intuicje.

W trzecim znaczeniu sąd intuicyjny to sąd wykraczający poza logikę, będący wynikiem przyjęcia przez badacza uproszczonej heurystyki. Efektem takiego poznania może być poprawny sąd, natomiast fałszywy wybór problemów badawczych, metod czy też tendencyjnych sądów jest spowodowany brakiem logicznej odwracalności. Kwestię tę można wyjaśnić na gruncie teorii operacji umysłowych autorstwa Jeana Piageta. W umyśle badacza problem pojawia się wtedy, kiedy nie potrafi on bezpośrednio wyjaśnić, na gruncie posiadanej wiedzy, biegu określonych zdarzeń. Wyrażając ten stan rzeczy w języku psychologii, powiedzielibyśmy, że umysł badacza znajduje się w stanie konfliktu poznawczego. W tym momencie aktywność badacza zmierza w kierunku sformułowania nowego programu działania, które umożliwi mu znalezienie rozwiązania dostrzeżonego problemu. $\mathrm{Na}$ 
tym etapie ważną rolę odgrywa myślenie symboliczne. Konflikty poznawcze poprzedzają problemy, one z kolei poprzedzane są przez sprzeczności i rozbieżności informacyjne. Subiektywne przejawy konfliktu odnoszą się do ciągu działań umysłowych, takich jak wieloznaczność, niejasność, złożoność, zaciekawienie itp. Nie stanowią one jednorodnych doznań umysłowych, ponieważ zawarte są w nich reakcje emocjonalne, oceny poznawcze i postawa badacza. Odkrycie problemu jest zatem spowodowane samodzielną czynnością umysłu badacza.

\section{Dylematy aksjologiczne w badaniach pedagogicznych}

W pedagogicznych badaniach naukowych, a w szczególności w ich przebiegu, uwidacznia się ich aspekt etyczny. Podczas badań pedagogicznych badacze są narażeni na konflikty i dylematy moralne. Konflikty aksjologiczne mogą się pojawiać w różnorodnych sytuacjach badawczych. Pragnę zwrócić uwagę na dwa rodzaje konfliktów: konflikt wartości typu „prawda - dobro”, przejawiający się w postaci „prawda - dobro” osób badanych i „prawda - dobro” badacza, oraz konflikt wartości typu „dobro - dobro" - odnoszący się do dobra osób badanych, dobra badaczy i odbiorców wiedzy (Spendel, 2005: 58-59). Pod pojęciem konfliktów aksjologicznych rozumie się zazwyczaj takie sytuacje, w których zachodzi niezgodność pomiędzy normami należącymi do różnych typów świadomości indywidualnej, bądź, jak twierdzi Spendel, pomiędzy normami należącymi do różnych typów świadomości (indywidualnej lub społecznej). Osobliwy przypadek stanowią takie sytuacje badawcze, w których zachodzi konflikt wartości przejawiający się wtedy, kiedy badacz podejmuje takie czynności badawcze, których efekty stanowią zarazem wyraz aprobaty dla uzyskanych w trakcie badań wartości poznawczych, jak i wyraz negacji wartości moralnych. Możliwa jest także sytuacja odwrotna. Warto podkreślić istnienie w praktyce badawczej również takich sytuacji, w których podjęcie czynności badawczych wyklucza jednoczesną aprobatę wartości cennych dla badacza i osób badanych. Podniesione względy upoważniają do stwierdzenia, że w praktyce badawczej mogą zachodzić konflikty „prawda - dobro” oraz „ dobro - dobro”.

\section{Konflikt wartości typu „prawda - dobro (osób badanych)”}

W badaniach empirycznych z udziałem ludzi mogą się ujawniać ograniczenia etyczne w warsztacie badawczym. Na przykład nie zawsze jest możliwe rygorystyczne przestrzeganie obowiązujących zasad w badaniach eksperymentalnych. Istnieje 
w nich niebezpieczeństwo naruszenia granic moralnych eksperymentu. Podobne niebezpieczeństwa mogą się pojawić przy zastosowaniu obserwacji lub innych metod. Badaczowi trudno jest na przykład przeprowadzić obserwację bez jakiejkolwiek ingerencji wtedy, kiedy osoby badane znajdują się w szczególnie trudnej dla siebie sytuacji. Badacz w tym momencie może przeżywać dylemat moralny. Konflikt ten może również mieć miejsce przy zastosowaniu modelu badań ex post facto, czy też ankiety lub wywiadu w takiej sytuacji, w której badacz będzie się odwoływał na przykład do momentów z przeszłości bardzo przykrych dla badanych.

\section{Konflikt wartości typu „prawda - dobro (badacza)”}

Charakter związku metodologii z etyką jest w tym przypadku dość kontrowersyjny, złożony i niejednoznaczny (Spendel, 2005: 60). Trudności, jakie napotyka badacz w wywiązywaniu się z obowiązku spełnienia przewidzianych przez metodologię standardów badawczych, jak również dysponowanie wysoce profesjonalnym warsztatem badawczym, mogą go skłaniać do niedoceniania czy wręcz ignorowania problemów etycznych związanych z badaniami, co w konsekwencji prowadzi do przyjęcia przez badacza postawy egocentrycznej, a w efekcie może naruszyć dobro osób badanych i zamknąć całkowicie lub częściowo drogę do prawdy w imię przyziemnych interesów własnych. Jeżeli badacz raz sprzeniewierzy się obowiązującym w metodologii badań pedagogicznych wartościom i ujdzie mu to bezkarnie, to może tak uczynić powtórnie, a nawet często postępować w ten sposób.

\section{Konflikt wartości typu „dobro (osób badanych) - dobro (badaczy i użyłkowników - odbiorców wiedzy)"}

Między interesem badacza i osób badanych może zachodzić sprzeczność. Na przykład w ramach refleksji nad wychowaniem może się pojawić pytanie o moralny sens daleko idącej ingerencji wychowawcy w osobowość wychowanka. Chodzi tu w szczególności o moralną ocenę tej ingerencji i jej roli w życiu ucznia (Spendel, 2005: 61).

Wymienione i pokrótce omówione dylematy nie wyczerpują całej listy dylematów, jakie stają przed badaczami prowadzącymi badania pedagogiczne, mogą jedynie uwrażliwiać na grożące niebezpieczeństwa. Z pewnością nie podważają jednak sensu badań pedagogicznych. 


\section{Uwagi końcowe}

Budowa teorii $\mathrm{w}$ danej dyscyplinie ułatwia aktywność poznawczą, dostarczając spójnego pojęciowo i metodologicznie systemu twierdzeń opisującego określoną klasę zjawisk tym, którzy daną dyscypliną się zajmują. Dydaktyka opisuje pewną część rzeczywistości pedagogicznej, stawiając pytania wyjaśniające, a w szczególności pytania dotyczące tego, jak proces kształcenia przebiega i jakich zmian należy w nim dokonać, by w uczniu mogły zachodzić zakładane wcześniej zmiany.

\section{Literatura}

Ablewicz K. (1998). Hermeneutyka i fenomenologia w badaniach pedagogicznych. [W:] S. Palka (red.). Orientacje w metodologii badań pedagogicznych. Kraków.

Biała Księga Kształcenia i Doskonalenia. Nauczanie i uczenie się na drodze do uczacego się społeczeństwa. (1997). Warszawa.

Brzeziński J. (1996). Metodologia badań psychologicznych. Warszawa.

Brzeziński J. (2007). Metodologia badań psychologicznych. Warszawa.

Delors J. (1998). Edukacja, jest w niej ukryty skarb. Warszawa.

Gnitecki J. (2006). Wstęp do ogólnej metodologii badań w naukach pedagogicznych. T. 1. Status metodologiczny nauk pedagogicznych. Poznan.

Kmita J. (1980). Szkice z epistemologii historycznej. Warszawa.

Kmita J. (1982). Scjentyzm i antyscjentyzm. [W:] Z. Cackowski (red.). Poznanie, umyst, kultura. Lublin.

Kruszewski K. (1987). Zmiana i wiadomość. Perspektywa dydaktyki ogólnej. Warszawa.

Malewski A. (1963). Szczeble ogólności teorii a proces wyjaśniania. „Studia Socjologiczne” nr 2, s. 62-63.

Muszyński H. (1970). Wstęp do metodologii pedagogiki. Warszawa.

Nęcka E., Orzechowski J., Szymura B. (2006). Psychologia poznawcza. Warszawa.

Palka S. (red.). (1998). Orientacje w metodologii badań pedagogicznych. Kraków.

Palka S. (2006). Metodologia. Badania. Praktyka pedagogiczna. Gdańsk.

Pawłowski T. (1988). Tworzenie pojęć w naukach humanistycznych. Warszawa.

Piotrowski E. (2010). Psychologiczne uwarunkowania badań pedagogicznych. [W:] S. Palka (red.). Podstawy metodologii badań w pedagogice. Gdańsk.

Spendel Z. (2005). Metodologia badań psychologicznych jako forma świadomości historycznej. Katowice. 
